\title{
Influence of gender and season on reduced glutathione concentration and energy reserves of Gammarus roeseli
}

\author{
Eric Gismondi*, Jean-Nicolas Beisel, Carole Cossu-Leguille \\ Laboratoire des Interactions Ecotoxicologie Biodiversité Ecosystèmes (LIEBE), CNRS UMR 7146, Université de Lorraine (UdL), Campus Bridoux, Bât. IBiSE, 8 Rue du Général \\ Delestraint, 57070 METZ, France
}

\section{A R T I C L E I N F O}

\section{Article history:}

Received 25 March 2012

Received in revised form

11 June 2012

Accepted 14 June 2012

\section{Keywords:}

Seasonal variations

Reduced glutathione

Gammarus roeseli

Biomarkers

Energy reserves

\begin{abstract}
A B S T R A C T
As biomarkers are known to be influenced by biotic and abiotic factors (e.g. gender, temperature), we investigated over a one-year long sampling period, the influence of season and gender on reduced glutathione concentrations and its synthesis in the crustacean amphipod Gammarus roeseli. At the same time, we assessed energy reserves and malondialdehyde levels as toxic biomarker. Results have shown that, in both genders, reduced glutathione concentrations were inversely correlated to water temperature, and higher in females than in males whatever the season. Total lipid and glycogen contents were higher in females than in males, allowing females to have enough energy to assume the reproductive period and maintain high GSH concentrations for detoxification processes. Conversely, females have lower cell damages than males. These differences between genders could induce differential sensitivity in a contamination context, and thus affect the population. Females could resist better than males in contaminated environments, especially in spring when reduced glutathione concentration is the highest.
\end{abstract}

(c) 2012 Elsevier Inc. All rights reserved.

\section{Introduction}

Biomarkers are tools used in environmental risk assessment (Galloway, 2006; Hagger et al., 2008). Some of them belong to defense mechanisms of organisms against oxidative damage caused by the formation of reactive oxygen species (ROS) (Sies, 1986). If enzymatic activities such as catalase (CAT, EC 1.11.1.6), superoxide dismutase (SOD), glutathione peroxidase (GPX, EC 1.11.1.9), glutathione S-transferase (GST, EC 2.5.1.18), ethoxyresorufin-O-deethylase (EROD) or acetylcholinesterase (AchE, EC 3.1.1.7) are widely studied in ecotoxicology as sensitive biomarkers (Cossu et al., 1997; Doyotte et al., 1997; Sroda and CossuLeguille, 2011a, 2011b), the free radical and xenobiotic scavengers of the non-enzymatic system such as glutathione (GSH) are poorly studied although they constitute also sensitive biomarkers (Regoli and Principato, 1995).

Among freshwater species, Gammarus sp. is a suitable organism for ecotoxicological assessment of environmental pollutants at a large scale, mostly because gammarid are present in most (if not all) river in Europe (Jażdżewski, 1980). Gammarids are known to be sensitive to pollutants and can easily be used for laboratory and field studies (Kunz et al., 2010). Hence, many ecotoxicological studies were carried out using gammarids to

\footnotetext{
* Corresponding author. Fax: +33 387378512.

E-mail address: eric.gismondi@hotmail.fr (E. Gismondi).
}

evaluate toxic impact of xenobiotics (Sornom et al., 2010; Khan et al., 2011; Sroda and Cossu-Leguille, 2011b). However, to our knowledge, no studies have been devoted to glutathione as a biomarker in Gammarus sp., although it could be the limiting factor for many antioxidant enzymes that use glutathione as a substrate and which are commonly assessed in these organisms (Correia et al., 2003; Bedulina et al., 2010; Sroda and CossuLeguille, 2011a,b).

Glutathione is a tripeptide widely distributed in animal and plant tissues. In its reduced form, it plays a central role into the detoxification system thanks to its thiol function which acts as a scavenger of organic or metallic xenobiotics (Griffith, 1999; Vasseur and Leguille, 2004). It participates in a lot of fundamental cellular processes, including protein synthesis, amino acid transport, enzymatic activity and cell defense against a wide range of stressors (Meister and Anderson, 1983; Singhal et al., 1987; Akira et al., 1990). It also plays an important role as a reducer which could prevent the toxic effect of ROS (Meister, 1988). Its contents have therefore been assayed in ecotoxicological studies about invertebrates, especially in bivalves (Doyotte et al., 1997; Canesi et al., 1999; Romero-Ruiz et al., 2003).

Due to the fact that biomarkers are known to be influenced by biotic and abiotic factors (e.g. gender, temperature) (Geffard et al., 2007; Bigot et al., 2011; Sroda and Cossu-Leguille, 2011a), in the present study, we investigated the influence of gender and season on the GSH concentrations and its synthesis (i.e. $\gamma$-glutamylcysteine ligase activity-GCL) in Gammarus roeseli, a widespread 
amphipod crustacean which originates from the Balkan area and has colonized several Western European rivers (Barnard and Barnard, 1983). At the same time, we measured the energy reserves by assaying glycogen and lipid contents. Glycogen represents a short-term energy source available for current activities (Sparkes et al., 1996), whereas lipids are used for long-term storage to be used as nutrients during starvation or reproduction periods (Cargill et al., 1985). Finally, we measured the levels of malondialdehyde (MDA), a product of lipid peroxidation considered as a toxicity biomarker which reflects cellular damage.

\section{Material and methods}

\subsection{Sampling and maintenance of $\mathrm{G}$. roeseli}

Males and females G. roeseli were sampled monthly from October 2008 to September 2009 with a hand net in the French Nied River (Laquenexy, Northeastern France, $49^{\circ} 05^{\prime} \mathrm{N}$ and $6^{\circ} 16^{\prime} \mathrm{E}$ ). Each month, water parameters such as temperature, $\mathrm{pH}$, conductivity, dissolved oxygen and oxygen saturation were measured in the field with a WTW Multi 340i/set measurement (Germany). Male and female gammarids were sorted on the spot according to gnathopod size, a sexual dimorphism character. They were then transported to the laboratory in river water, where four pools of seven males and four pools of ten females were formed to measure biomarkers and energy reserves. Each pool was frozen in nitrogen liquid and maintained four weeks at $-80^{\circ} \mathrm{C}$ awaiting biomarker analyses. Prior to analysis, G. roeseli gender was checked by observing genital papillas, which are present in males only, on the 7th ventral segment.

\subsection{Biomarkers measurement}

\subsubsection{Sample preparation}

Each pool was homogenized with a manual Potter Elvejhem tissue grinder in a $50 \mathrm{mM}$ phosphate buffer $\mathrm{KH}_{2} \mathrm{PO}_{4} / \mathrm{K}_{2} \mathrm{HPO}_{4}(\mathrm{pH} 7.6$ ) supplemented with $1 \mathrm{mM}$ phenylmethyl sulphonylfluoride (PMSF), and $1 \mathrm{mM}$ L-serine-borate mixture as proteases inhibitors, and $5 \mathrm{mM}$ phenylglyoxal as a $\gamma$-glutamyl transpeptidase inhibitor. The homogenization buffer was adjusted to a volume two-fold the wet weight of the sample pool (e.g. $400 \mu \mathrm{L}$ of homogenization buffer for $200 \mathrm{mg}$ of wet weight tissue) (adapted from Cossu et al. (1997) and Doyotte et al. (1997)). The tissue was crushed by four turns of Potter followed by a homogenization of the mixture with a vortex and another 4 turns of Potter to obtain the homogenate. The homogenate was divided into five parts to measure the different parameters. For each pool, two independent measurements were performed for each biomarker, and the mean was used for statistical analyses.

\subsubsection{Biomarkers assays}

GSH concentrations measurement was adapted from Leroy et al. (1993) using High-Pressure Liquid Chromatography (HPLC) separation. The proteins of $40 \mu \mathrm{L}$ of the total homogenate were precipitated with $10 \%$ perchloric acid $(v / v)$. After a 10 -min centrifugation at $20,000 \times g$ at $4{ }^{\circ} \mathrm{C}$, the resulting supernatant was diluted 40 -fold in $0.1 \mathrm{M}$ hydrochloric acid $(\mathrm{HCl}) .20 \mu \mathrm{L}$ of the diluted supernatant were injected in a reverse-phase LiChrospher $100 \mathrm{RP} 18$-encapped column $(125 \mathrm{~mm} \times$ $4 \mathrm{~mm}, 5 \mu \mathrm{m}$ ) and separation was carried out at $25^{\circ} \mathrm{C}$. Elution was performed with $7 \%$ acetonitrile (Chromanorm, 95\%) in a $0.01 \mathrm{M}$ phosphate buffer ( $\mathrm{pH} 2.5$ ) containing $0.5 \mathrm{mM} n$-decylsodiumsulfate as an ion-pairing reagent. Commercial GSH diluted in $0.1 \mathrm{M} \mathrm{HCl}$ was used as a standard and GSH concentrations were expressed in $\mathrm{nmol} \mathrm{mg}^{-1}$ protein.

$\gamma$-glutamylcysteine ligase activity (GCL) was assayed using an HPLC method adapted from Parmentier et al. (1998). Measurements were carried out on the S12000 fraction obtained after centrifuging $40 \mu \mathrm{L}$ of the total homogenate for $15 \mathrm{~min}$ at $500 \times \mathrm{g}$ and then centrifuging the resulting supernatant at $12,000 \times \mathrm{g}$ and $4{ }^{\circ} \mathrm{C}$ for $30 \mathrm{~min}$. The resulting S12000 fraction was diluted 20 -fold in the homogenization buffer and $40 \mu \mathrm{L}$ of this diluted solution were added to $112 \mu \mathrm{L}$ of incubation cocktail $\left(0.5 \mathrm{M}\right.$ Tris- $\mathrm{HCl}, 200 \mathrm{mM} \mathrm{MgCl} \cdot 6 \mathrm{H}_{2} \mathrm{O}, 500 \mathrm{mM} \mathrm{KCl}, 45 \mathrm{mM}$ glutamic acid, $90 \mathrm{mM}$ cysteine, $1 \mathrm{mM}$ DTT, $90 \mathrm{mM}$ ATP, $0.5 \mathrm{mM}$ phenylglyoxal, $\mathrm{pH}$ 8.25 ) to initiate the reaction. After a 20 min-incubation period at $25^{\circ} \mathrm{C}$, the reaction was stopped by a four-fold dilution with $0.1 \mathrm{M} \mathrm{HCl} .20 \mu \mathrm{L}$ of the resulting solution were injected into a LiChrospher 100 RP18-encapped HPLC column $(125 \mathrm{~mm} \times 4 \mathrm{~mm}, 5 \mu \mathrm{m})$. Commercial glutamylcysteine (GC) solution was used as a standard and GCL activity was expressed in nmol GC $\mathrm{min}^{-1} \mathrm{mg}^{-1}$ protein.

The total protein content of each sample was quantified according to Bradford (1976) with bovine serum albumin (BSA) as a standard. Results were expressed in $\mathrm{mg} \mathrm{mL}^{-1}$.

\subsubsection{Lipid peroxidation}

MDA levels were measured with an HPLC method adapted from Behrens and Madère (1991) with UV detection at $267 \mathrm{~nm}$. $70 \mu \mathrm{L}$ of the total homogenate were diluted four-fold with $95 \%$ ethanol (HPLC grade) and cooled on ice for 1.5 hrs to deproteinize them. The mixture was then centrifuged at $18,000 \times g$ for $30 \mathrm{~min}$ at $4{ }^{\circ} \mathrm{C}$. $100 \mu \mathrm{L}$ of the resulting supernatant were injected directly into a reversedphase LiChrospher 100RP18-encapped HPLC column. The separation was conducted at $25^{\circ} \mathrm{C}$ and elution was carried out with sodium phosphate buffer ( $\mathrm{pH} 6.5$ ) containing $25 \%$ ethanol and $0.5 \mathrm{mM}$ tetradecylmethylammonium bromide as an ion-paring reagent. MDA standard was prepared by hydrolyzing $24 \mu \mathrm{L}$ of $1,1,3,3$ tetraethoxy-propan $97 \%$ (TEP) in $10 \mathrm{~mL}$ of sulfuric acid $1 \%$ for $2 \mathrm{~h}$ in the dark. The hydrolyzed solution was then diluted 20 -fold in sulfuric acid, and diluted once more 10-fold in phosphate buffer ( $\mathrm{pH} \mathrm{7.6).} \mathrm{Optical} \mathrm{density} \mathrm{of} \mathrm{this} \mathrm{diluted} \mathrm{solution} \mathrm{was}$ measured at $245 \mathrm{~nm}$ to estimate the concentration of the solution thanks to the molar extinction coefficient $\left(\varepsilon=13,700 \mathrm{~L} \mathrm{~mol}^{-1} \mathrm{~cm}^{-1}\right)$. The MDA standard curve was composed of 5 concentrations: $0.125,0.25,0.5,1$ and $2 \mu \mathrm{M}$ obtained by dilution of the prepared solution. MDA levels were expressed in $\mathrm{ng} \mathrm{MDA} \mathrm{mg}^{-1}$ lipid.

\subsubsection{Energy reserves}

The measurement of total lipid and glycogen contents was adapted from Plaistow et al. (2001). $20 \mu \mathrm{L}$ of $2 \%$ sodium sulfate (w/v) and $540 \mu \mathrm{L}$ of chloroform/ methanol $1: 2(\mathrm{v} / \mathrm{v})$ were added to $40 \mu \mathrm{L}$ of total homogenate. After $1 \mathrm{~h}$ on ice, the samples were centrifuged at $3000 \times g$ for $5 \mathrm{~min}$ at $4{ }^{\circ} \mathrm{C}$. The resulting supernatant and the pellet were used to determine the total lipid and glycogen contents, respectively.

$100 \mu \mathrm{L}$ of the supernatant were transferred into culture tubes and placed in a dry bath at $95{ }^{\circ} \mathrm{C}$ to evaporate the solvent. Then, $200 \mu \mathrm{L}$ of $95 \%$ sulfuric acid were added in each tube and left for $10 \mathrm{~min}$. The culture tubes were cooled on ice and then $4.8 \mathrm{~mL}$ of a vanillin-phosphoric acid reagent were added. After a 10-min reaction, the optical density was measured at $535 \mathrm{~nm}$. Commercial cholesterol was used as a standard and lipid contents were expressed in $\mathrm{mg} \mathrm{mL}^{-1}$.

Total dissolution of the pellet was performed in $400 \mu \mathrm{L}$ of deionized water for $10 \mathrm{mi}$ in an ultrasonic bath. $100 \mu \mathrm{L}$ of each sample were placed in culture tubes and $4.9 \mathrm{~mL}$ of anthrone reagent were added. The mixture was placed in a dry bath at $95{ }^{\circ} \mathrm{C}$ for $17 \mathrm{~min}$ and then cooled on ice. Optical density was measured at $625 \mathrm{~nm}$. Glucose was used as a standard and concentrations were expressed in $\mu \mathrm{g} \mathrm{mg}^{-1}$ wet weight.

\subsubsection{Statistical analysis}

Data analysis was performed using a multivariate analysis of variance (MANOVA, Pillai's trace) with respect to "gender" and "sampling month" as fixed factors. All data met normality and homogeneity of variance assumptions. Since the MANOVA test was significant, each biomarker was then analyzed using ANOVA tests, followed by the TukeyHSD post-hoc test. All tests were performed with a 5\% type I error risk, using R 2.9.0 Software.

\section{Results}

\subsection{Water parameters}

Monthly measured physico-chemical parameters are summarized in Table 1. Among the different parameters we measured, temperature was the most variable with a coefficient of variation of $55.2 \%$, whereas $\mathrm{pH}$ was the least variable. Indeed, temperature ranged from $2.3{ }^{\circ} \mathrm{C}$ in January to $20^{\circ} \mathrm{C}$ in June. All other parameters were stable over time and mean values for $\mathrm{pH}$, conductivity, dissolved oxygen and oxygen saturation were respectively 8.1, $1403.8 \mu \mathrm{sm}^{-1}, 10.3 \mathrm{mg} \mathrm{L}^{-1}$ and $95.4 \%$.

\subsection{Seasonal variations}

Global MANOVA analysis revealed an effect of individual gender, sampling month, and of their interactions on the variations of biomarker levels (Table 2). The results are detailed below for each biomarker category.

\subsubsection{GSH concentration, GCL activity and biomarker of toxicity}

Reduced glutathione concentrations measured over one year in G. roeseli were influenced by gender and sampling month (Table 2 ). For both genders, GSH concentrations were higher in winter (from November to February) and lower in summer (from May to August) (Fig. 1). Moreover, overall, females had higher GSH concentrations 
Table 1

Physico-chemical parameters of the Nied River at Laquenexy measured at each sampling date. Means, standard deviations and coefficient of variation are presented at the end of the table.

\begin{tabular}{llllllc}
\hline & $\begin{array}{l}\text { Temperature } \\
\left({ }^{\circ}\right)\end{array}$ & pH & $\begin{array}{l}\text { Conductivity } \\
\left(\boldsymbol{\mu S} \mathbf{~ c m}^{-1}\right)\end{array}$ & $\begin{array}{l}\text { Dissolved } \\
\text { oxygen } \\
\left(\mathbf{m g ~ L}^{-1}\right)\end{array}$ & $\begin{array}{l}\text { Oxygen } \\
\text { saturation } \\
(\%)\end{array}$ \\
\hline $\mathbf{2 0 0 8}$ & Oct & 9.6 & 8.1 & 1722.0 & 11.0 & 97.8 \\
& Nov & 8.6 & 8.0 & 1460.0 & 10.0 & 84.4 \\
Dec & 3.6 & 7.9 & 1136.0 & 10.8 & 81.4 \\
$\mathbf{2 0 0 9}$ & Jan & 2.3 & 8.0 & 1135.0 & 11.1 & 81.5 \\
Feb & 4.9 & 8.3 & 1051.0 & 10.7 & 84.7 \\
Mar & 9.0 & 8.3 & 1091.0 & 12.5 & 108.6 \\
Apr & 12.7 & 8.2 & 1353.0 & 9.9 & 97.3 \\
May & 17.3 & 8.0 & 1463.0 & 9.1 & 96.0 \\
Jun & 20.0 & 8.4 & 1580.0 & 11.0 & 123.8 \\
Jul & 19.6 & 7.8 & 1171.0 & 6.4 & 71.9 \\
Aug & 20.5 & 8.2 & 1685.0 & 10.4 & 105.3 \\
Sep & 17.1 & 8.1 & 1998.0 & 10.5 & 111.9 \\
Mean & $\mathbf{1 2 . 1}$ & $\mathbf{8 . 1}$ & $\mathbf{1 3 8 7 . 1}$ & $\mathbf{1 0 . 3}$ & $\mathbf{9 5 . 4}$ \\
SD & $\mathbf{6 . 7}$ & $\mathbf{0 . 2}$ & $\mathbf{3 2 6 . 4}$ & $\mathbf{1 . 5}$ & $\mathbf{1 5 . 2}$ \\
VC\% & $\mathbf{5 5 . 2}$ & $\mathbf{2 . 1}$ & $\mathbf{2 3 . 5}$ & $\mathbf{1 4 . 2}$ & $\mathbf{1 5 . 9}$ \\
\hline
\end{tabular}

Table 2

Multivariate (Pillai's trace) and univariate analyses of variance investigating variation in energy reserves (protein, lipid, glycogen), defense capacities (GSH, $\mathrm{GCL}$ ) and in biomarker of toxicity (MDA) of G. roeseli, as a function of gender and sampling month.

\begin{tabular}{|c|c|c|c|c|c|}
\hline Models & Parameter & $\begin{array}{l}\text { Source of } \\
\text { variation }\end{array}$ & $\begin{array}{l}\text { num d.f. }{ }^{a} \text {, den } \\
\text { d.f. }^{b}\end{array}$ & $\mathbf{F}$ & $\boldsymbol{P}$ \\
\hline \multirow[t]{4}{*}{ MANOVA } & & Whole model & 138,432 & 17.44 & $<\mathbf{0 . 0 0 0 1}^{\mathrm{c}}$ \\
\hline & & Gender & 6,67 & 47.46 & $<0.0001$ \\
\hline & & Month & 66,432 & 24.04 & $<0.0001$ \\
\hline & & Gender: Month & 66,432 & 5.61 & $<0.0001$ \\
\hline \multirow[t]{24}{*}{ ANOVAs } & Proteins & Whole model & 23,72 & 18.85 & $<0.0001$ \\
\hline & & Gender & 1,72 & 92.61 & $<\mathbf{0 . 0 0 0 1}$ \\
\hline & & Month & 11,72 & 27.85 & $<\mathbf{0 . 0 0 0 1}$ \\
\hline & & Gender: Month & 11,72 & 3.15 & 0.0016 \\
\hline & Total & Whole model & 23,72 & 38.73 & $<0.0001$ \\
\hline & & Gender & 1,72 & 214.61 & $<0.0001$ \\
\hline & & Month & 11,72 & 42.01 & $<0.0001$ \\
\hline & & Gender: Month & 11,72 & 19.46 & $<0.0001$ \\
\hline & Glycogen & Whole model & 23,72 & 13.26 & $<0.0001$ \\
\hline & & Gender & 1,72 & 22.82 & $<0.0001$ \\
\hline & & Month & 11,72 & 23.74 & $<\mathbf{0 . 0 0 0 1}$ \\
\hline & & Gender: Month & 11,72 & 1.90 & 0.0520 \\
\hline & GSH & Whole model & 23,72 & 15.45 & $<0.0001$ \\
\hline & & Gender & 1,72 & 39.04 & $<0.0001$ \\
\hline & & Month & 11,72 & 23.94 & $<0.0001$ \\
\hline & & Gender: Month & 11,72 & 4.81 & $<\mathbf{0 . 0 0 0 1}$ \\
\hline & GCL & Whole model & 23,72 & 30.64 & $<0.0001$ \\
\hline & & Gender & 1,72 & 0.20 & 0.6544 \\
\hline & & Month & 11,72 & 50.88 & $<0.0001$ \\
\hline & & Gender: Month & 11,72 & 13.16 & $<\mathbf{0 . 0 0 0 1}$ \\
\hline & MDA & Whole model & 23,72 & 24.56 & $<0.0001$ \\
\hline & & Gender & 1,72 & 95.28 & $<0.0001$ \\
\hline & & Month & 11,72 & 29.14 & $<0.0001$ \\
\hline & & Gender: Month & 11,72 & 13.54 & $<0.0001$ \\
\hline
\end{tabular}

\footnotetext{
a Numerator degrees of freedom

Denominator degrees of freedom

c Significant values shown in bold
}

than males. In females, the highest values were measured in March and April with an average $4.5 \mathrm{nmol} \mathrm{GSH} \mathrm{mg}{ }^{-1}$ protein, while in males, the highest GSH concentrations were observed in January
(3.7 nmol GSH mg ${ }^{-1}$ protein). Finally, in both genders, GSH concentrations were negatively correlated to water temperature $(r=-0.68$, $p$-value $<0.001 ; r=-0.79, p$-value $<0.001$, for females and males respectively, Pearson correlation).

GCL activity variations were significantly dependent of sampling month (Table 2, Fig. 2). No significant difference was determined according to gender: the annual mean value of GCL activity was 0.34 and $0.35 \mathrm{nmol} \mathrm{GC} \mathrm{min}{ }^{-1} \mathrm{mg}^{-1}$ protein for females and males, respectively. In both genders, GCL activity was lower from October to April (winter), except in January, with

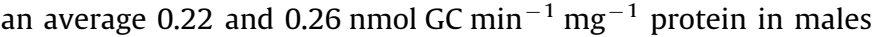
and females, respectively. The highest activities were measured from May to September (summer) and were about 0.41 and $0.43 \mathrm{nmol} \mathrm{GC} \mathrm{min}^{-1} \mathrm{mg}^{-1}$ protein for females and males, respectively. Finally, it was defined that in females, GCL activity was positively correlated with water temperature $(r=0.38$, $p$-value $<0.001$, Pearson correlation).

MDA levels were influenced by gender, sampling month and the interactions between these two factors (Table 2, Fig. 3). Males had higher MDA levels than females, regardless of the month (Fig. 3). Indeed, the annual MDA mean level in males was $6.60 \mathrm{ng} \mathrm{mg}^{-1}$ lipid and ranged from $2.74 \mathrm{ng} \mathrm{mg}^{-1}$ lipid in August to $14.44 \mathrm{ng} \mathrm{mg}^{-1}$ lipid in March, whereas females exhibited an average $4.26 \mathrm{ng} \mathrm{mg}^{-1}$ lipid and ranged from $2.00 \mathrm{ng} \mathrm{mg}^{-1}$ lipid in February to $7.78 \mathrm{ng} \mathrm{mg}^{-1}$ lipid in June. Significant differences between males and females were mainly observed in spring (from February to May).

\subsubsection{Energy reserves}

Total lipid contents were influenced by gender, sampling month and the interactions between these two factors (Table 2). Total lipid contents were higher in females than in males (Table 3) with annual mean lipid contents of $4.91 \mathrm{mg} \mathrm{mL}^{-1}$ and $3.33 \mathrm{mg} \mathrm{mL}^{-1}$, respectively. Significant differences between males and females were observed all year long, except in November and January. For both genders, the lowest total lipid content was measured in September with $2.91 \mathrm{mg} \mathrm{mL}^{-1}$ and $1.52 \mathrm{mg} \mathrm{mL}^{-1}$ in females and males, respectively; while the highest values were observed in February for females (8.36 $\mathrm{mg} \mathrm{mL}^{-1}$ ) and in August for males (5.72 $\mathrm{mg} \mathrm{mL}^{-1}$ ).

Glycogen content was influenced by gender and the interaction between gender and sampling month (Tables 2 and 3). Significant differences between males and females were observed during the spring period, from March to June. In males, glycogen contents ranged from $0.79 \mu \mathrm{g} \mathrm{mg}^{-1}$ tissue in March to $7.04 \mu \mathrm{g} \mathrm{mg}^{-1}$ tissue in December; while in females, it ranged from $2.58 \mu \mathrm{g} \mathrm{mg}^{-1}$ tissue in October to $7.54 \mu \mathrm{g} \mathrm{mg}^{-1}$ tissue in December.

\section{Discussion}

This study was carried out to investigate the influence of the gender and the season on antitoxic defense capacities of the amphipod G. roeseli, especially on the GSH concentration and its synthesis. At the same time, variations of lipid and glycogen contents as well as MDA levels, according to gender and season, were assessed.

Results highlighted a seasonal variation in GSH concentrations, since they were higher in autumn and winter, then decreased in spring and finally reached their lowest in summer, in both genders. This decrease in GSH concentration could be explained by the rise in temperatures, resulting in an increase in oxygen consumption, as observed in G. limnaeus (Krog, 1954) and in G. fossarum (Issartel et al., 2005). In fact, an increase in oxygen consumption could favor the formation of ROS as described by 


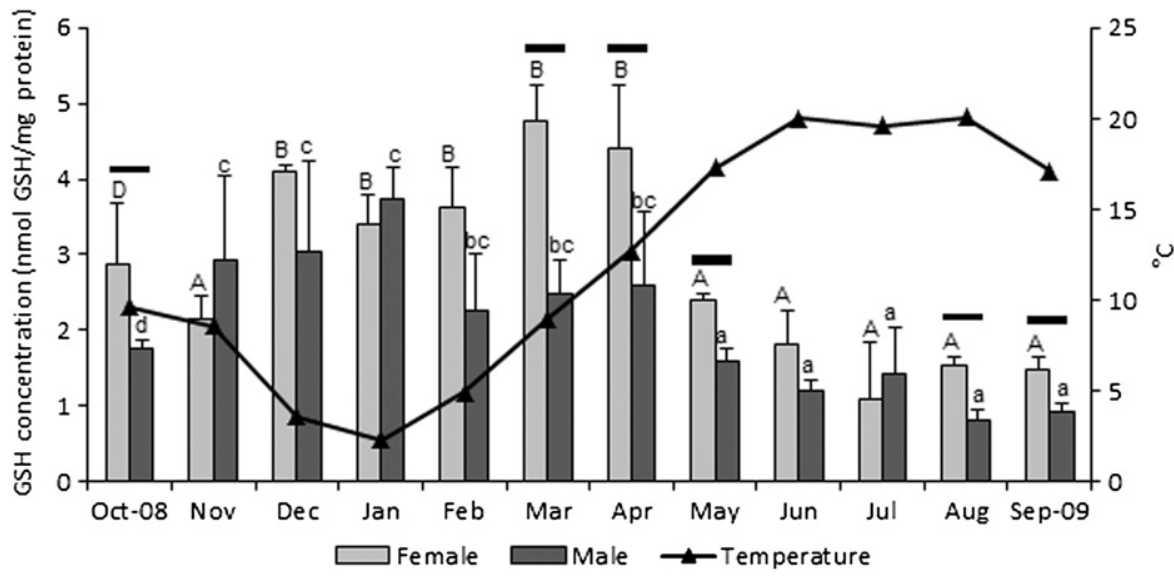

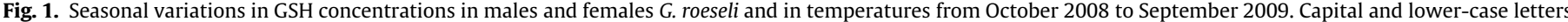

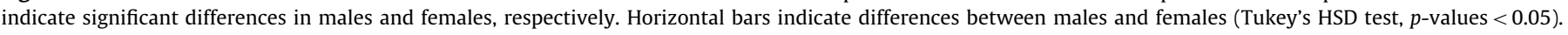

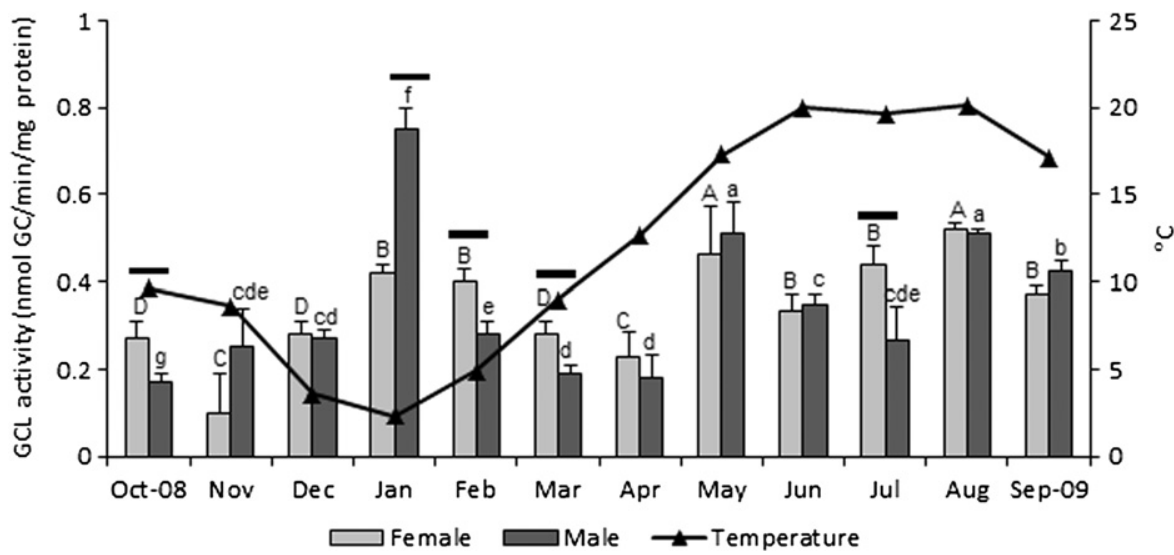

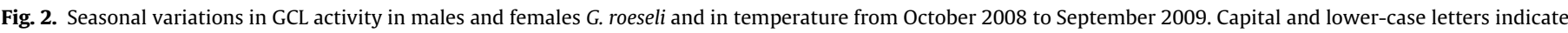
significant differences in males and females, respectively. Horizontal bars indicate differences between males and females (Tukey's HSD test, $p$-values $<0.05$ ).

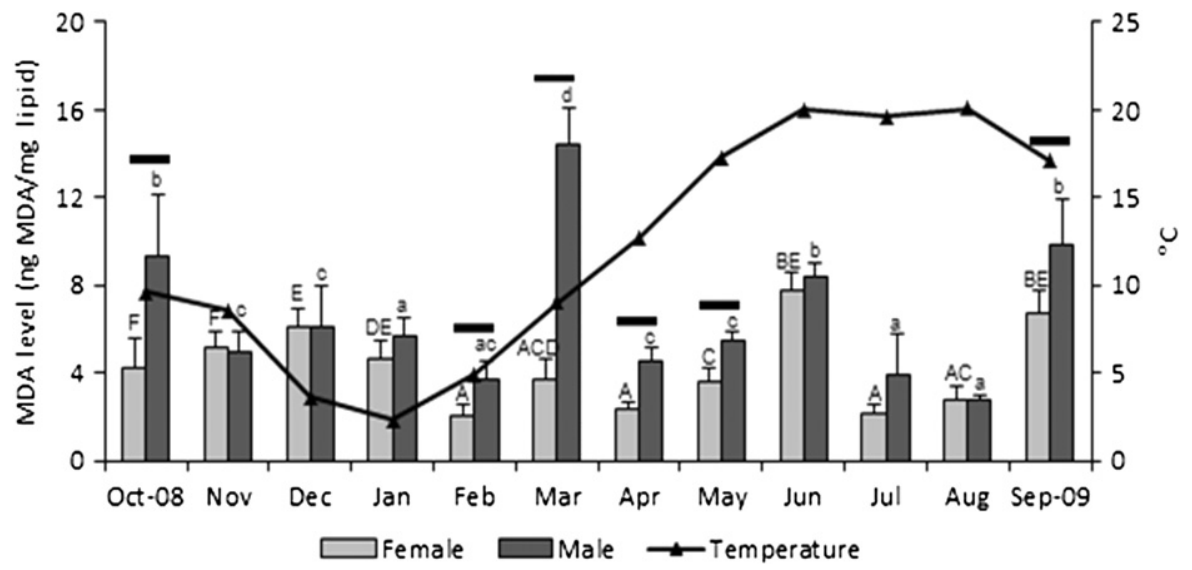

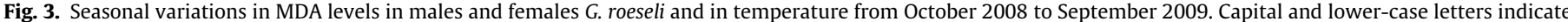
significant differences in males and females, respectively. Horizontal bars indicate differences between males and females (Tukey's HSD test, $p$-values $<0.05$ ).

Verlecar et al. (2007) in the brown mussel Perna viridis. Thus, to prevent the cellular damage caused by high ROS levels in summer, GSH could be used for detoxification, resulting in its decrease. Similar variations were observed in other organism such as the mussel $P$. viridis (Verlecar et al., 2008); nevertheless, inverse variations have been observed as for example in the bivalves Mytilus edulis and P. perna (Power and Sheehan, 1996; Wilhelm Filho et al., 2001).
The hypothesis of a higher GSH mobilization during summer in $G$. roeseli males and females is supported by the fact that GCL activity was higher in summer in both genders compared to autumn and winter. This high GCL activity reflects high GSH production. Consequently, our results suggest that high levels of GSH are produced in summer and are likely to be used for cell defense, suggesting that the conversion of oxidized glutathione (GSSG) to reduced form by the glutathione reductase (GR, 1.8.1.7) 
Table 3

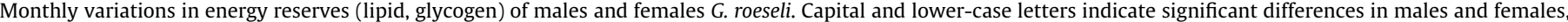

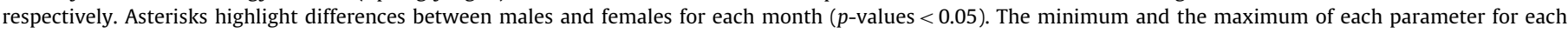
gender are indicated in bold type.

\begin{tabular}{|c|c|c|c|c|}
\hline \multirow[t]{2}{*}{ Month $\left({ }^{\circ} \mathbf{C}\right)$} & \multicolumn{2}{|c|}{ Total lipid content } & \multicolumn{2}{|c|}{ Glycogen content } \\
\hline & Males & Females & Males & Females \\
\hline Oct (9.6) & $2.67 \pm 0.52^{\mathrm{ab}}$ & $5.45 \pm 0.96^{\mathrm{A} *}$ & $3.34 \pm 0.43^{a}$ & $2.58 \pm 0.63^{A}$ \\
\hline Nov (8.6) & $3.27 \pm 1.00 \mathrm{bc}$ & $3.54 \pm 0.98^{\mathrm{B}}$ & $2.51 \pm 0.72^{a}$ & $2.59 \pm 1.41^{\mathrm{A}}$ \\
\hline $\operatorname{Dec}(3.6)$ & $2.54 \pm 0.54 \mathrm{ab}$ & $4.97 \pm 0.59 \mathrm{AC} *$ & $7.04 \pm 1.90^{b}$ & $7.54 \pm 2.38^{B}$ \\
\hline $\operatorname{Jan}(2.3)$ & $3.56 \pm 0.09 \mathrm{bcd}$ & $3.74 \pm 0.32^{\mathrm{ABC}}$ & $3.53 \pm 0.66^{\mathrm{a}}$ & $4.28 \pm 0.50 \mathrm{AC}$ \\
\hline Feb (4.9) & $4.92 \pm 0.92^{d}$ & $8.36 \pm 0.59$ D* & $3.62 \pm 0.33^{a}$ & $4.03 \pm 0.20^{\mathrm{AC}}$ \\
\hline $\operatorname{Mar}(9.0)$ & $1.55 \pm 0.11^{\mathrm{a}}$ & $3.76 \pm 0.37^{\mathrm{BC} *}$ & $0.79 \pm 0.28^{c}$ & $2.60 \pm 0.32^{\mathrm{A} *}$ \\
\hline Apr (12.7) & $3.38 \pm 0.24 \mathrm{bc}$ & $5.83 \pm 0.43^{\text {ACE } *}$ & $2.19 \pm 0.43^{a}$ & $3.13 \pm 0.32^{\mathrm{A} *}$ \\
\hline May (17.3) & $4.16 \pm 0.16^{\mathrm{cd}}$ & $7.35 \pm 0.63^{\mathrm{D} *}$ & $1.94 \pm 0.43^{a}$ & $4.23 \pm 0.62 \mathrm{AC} *$ \\
\hline Jun (20.0) & $3.07 \pm 0.20^{\mathrm{b}}$ & $4.85 \pm 0.35$ АCE* & $2.18 \pm 0.24^{\mathrm{a}}$ & $3.27 \pm 0.33^{\mathrm{A} *}$ \\
\hline Jul (19.6) & $3.62 \pm 0.48$ bcd & $4.94 \pm 0.55$ АСЕ $*$ & $4.06 \pm 0.73^{a}$ & $4.95 \pm 0.45^{\mathrm{C}}$ \\
\hline Aug (20.5) & $3.22 \pm 0.22 \mathrm{bcd}$ & $5.72 \pm 0.13$ АCE* & $2.49 \pm 0.09^{a}$ & $2.79 \pm 0.74^{\mathrm{A}}$ \\
\hline Sep (17.1) & $1.52 \pm 0.10^{a}$ & $2.91 \pm 0.20^{B *}$ & $2.67 \pm 0.71^{a}$ & $4.04 \pm 0.38^{\mathrm{AC}}$ \\
\hline Annual mean & $3.12 \pm 0.38$ & $5.12 \pm 0.51^{*}$ & $3.03 \pm 0.58$ & $3.83 \pm 0.69$ \\
\hline
\end{tabular}

activity is not sufficient enough to maintain the GSH concentration needed.

In parallel of the seasonal influence, results highlighted gender-based GSH concentrations, as G. roeseli females had higher GSH concentrations than males. This higher GSH content in females, as compared to males, could be linked to higher activities of antioxidant enzymes using GSH as a substrate (e.g. seleniumdependent glutathione peroxidase-Sroda and Cossu-Leguille (2011a)). The difference in GSH concentrations between males and females could also be caused by the physiological status of the organisms. The GSH variations could be related to the changing metabolic status of the organism. Indeed, Viarengo et al. (1991) and Wilhelm Filho et al. (2001) have shown a close link between GSH concentrations and the reproduction cycle in Mytilus sp. and P. perna, respectively. In G. roeseli, Pöckl (1992) showed that sexual maturity was reached faster at $16-20{ }^{\circ} \mathrm{C}$, which corresponds to the temperatures measured from May to September on our study site. Therefore, the higher GSH concentrations measured in March and April, especially in females, could be an adaptation of the organism to increase their defense capacities before the breeding period (Knapen et al., 1999). Higher defense capacities observed in females allow us to hypothesize that females could be less sensitive than males in a contamination context. This hypothesis is supported by the measurement of lower MDA levels in G. roeseli females than in males ones (this study; Sroda and Cossu-Leguille, 2011a), reflecting lower cell damage, but also by the fact that in our previous study, we demonstrated that the $\mathrm{LC}_{50}$ value (lethal concentration 50) was higher in females exposed to cadmium stress than males, suggesting higher resistance of females (Gismondi et al., 2012).

Energy reserves in $G$. roeseli were influenced by season and gender. Indeed, in both genders, higher energy reserves were measured in autumn and winter, and lower energy reserves were measured in spring and summer. The highest energy reserves in autumn could be the consequence of the leaf-fall which increased the food-source for gammarids, as suggested by Sutcliffe, 1993, while the decrease in summer could be explain by the energy mobilization for the reproductive period. Indeed, in females, the decrease of lipid and glycogen contents were measured from June to September, which corresponds to the reproductive period, linked to the oogenesis process. This process involves the vitellus production (required for eggs development) which uses lipids (Rosa and Nunes, 2002), and pleopod beats (considered as brood care for juveniles oxygenation-Dick et al., 1998) which could use glycogen (short-term energy-Sparkes et al., 1996). Conversely, the high lipid content measured in February in females could be explained by the maturation period. This hypothesis is supported by Clarke et al. (1985) who observed an increase in lipid contents during the different maturation stages of female in G. oceanicus. Although in females, the decrease of energy reserves could be explain by the breeding period; in males, the lowest glycogen contents measured in spring could be explained by an increase of the locomotor activity to seek for receptive females for breeding, as supposed by Plaistow et al. (2003) and Sroda and Cossu-Leguille (2011a). In opposition, the higher glycogen contents in winter (i.e. December) in both genders could be the consequence to a slower metabolism (e.g. a weak locomotor activity), due to low temperature.

In our study, the difference in energy reserves between males and females could explain the gender-based GSH concentrations. This hypothesis was supported by the fact that the energy reserves depletion observed in spring corresponds to an increase of the GCL activity. Indeed, GSH synthesis is performed by two successive ATP-dependent reactions (Meister and Anderson, 1983), which consume energy coming from lipids and glycogen degradation. Thus, higher energy reserves in females allows them to have a higher activity of GCL and therefore produce higher concentrations of GSH, as it was also observed for antioxidant enzyme activities in G. roeseli (Sroda and Cossu-Leguille, 2011a).

\section{Conclusion}

The present work highlighted variations in GSH concentrations, GCL activity and energy reserves in G. roeseli according to gender and season. All parameters were higher in females compared to males suggesting that (i) they could have a better antitoxic defense, and (ii) could assume the antitoxic defense and reproduction costs. Moreover, considering our results, it would therefore be cautious to consider gender and season as confounding factors in ecotoxicological studies using gammarids as biological models, in order to interpret biomarker responses more relevantly as possible. However, it could also be interesting to compare our population's results to another population of gammarid, since previous studies highlighted a variation in the detoxification response according to the population sampled (Damiens et al., 2006).

\section{Acknowledgments}

The Ph.D. thesis of Eric Gismondi was supported by the French Ministry of Education and Research (Ministère de l'Enseignement 
Supérieur et de la Recherche) which we sincerely thank here. The present work was funded by the EC2CO research program (Ecosphère Continentale et Côtière) and the Zone Atelier Moselle (ZAM, Région Lorraine). We are grateful to Annie Buchwalter for improving the English text.

\section{References}

Akira, N., Anderson, M.E., Meister, A., 1990. Cellular glutathione as a determinant of sensitivity to mercuric chloride toxicity: prevention of toxicity by giving glutathione monoester. Biochem. Pharmacol. 40, 693-697.

Barnard, J.L., Barnard, C.M., 1983. Freshwater Amphipoda of the World I \& II. Hayfield Associates, Mt. Vernon.

Bedulina, D.S., Timofeyev, M.A., Zimmer, M., Zwirnmann, E., Menzel, R., Steinberg, C.E.W., 2010. Different natural organic matter isolates cause similar stress response patterns in the freshwater amphipod, Gammarus pulex. Environ. Sci. Pollut. Res. 17, 261-269.

Behrens, W., Madère, R., 1991. Malonaldehyde determination in tissues and biological fluids by ion-pairing high-performance liquid chromatography. Lipids 26, 232-236.

Bradford, M.M., 1976. A rapid and sensitive method for the quantitation of microgram quantities of protein utilizing the principle of protein-dye binding. Anal. Biochem. 72, 248-254.

Bigot, A., Doyen, P., Vasseur, P., Rodius, F., 2011. Early defense responses in the freshwater bivalve Corbicula fluminea exposed to copper and cadmium: transcriptional and histochemical studies. Environ. Toxicol. 26, 623-632.

Canesi, L., Viarengo, A., Leonzio, C., Filippelli, M., Gallo, G., 1999. Heavy metals and glutathione metabolism in mussel tissues. Aquat. Toxicol. 46, 67-76.

Cargill, A.S., Cummins, K.W., Hanson, B.J., Lowry, R.R., 1985. The role of lipids as feeding stimulants for shredding aquatic insects. Freshwater Biol. 15, 455-464.

Clarke, A., Skadsheim, A., Holmes, L.J., 1985. Lipid biochemistry and reproductive biology in two species of Gammaridae (Crustacea: Amphipoda). Mar. Biol. 88, 247-263.

Correia, A.D., Helena Costa, M., Luis, O.J., Livingstone, D.R., 2003. Age-related changes in antioxidant enzyme activities, fatty acid composition and lipid peroxidation in whole body Gammarus locusta (Crustacea: Amphipoda). J. Exp. Mar. Biol. Ecol. 289, 83-101.

Cossu, C., Doyotte, A., Jacquin, M.C., Babut, M., Exinger, A., Vasseur, P., 1997. Glutathione reductase, selenium-dependent glutathione peroxidase, glutathione levels, and lipid peroxidation in freshwater bivalves, Unio tumidus, as biomarkers of aquatic contamination in field studies. Ecotoxicol. Environ. Saf. 38, 122-131.

Damiens, G., Mouneyrac, C., Quiniou, F., His, E., Gnassia-Barelli, M., Roméo, M., 2006. Metal bioaccumulation and metallothionein concentrations in larvae of Crassostrea gigas. Environ. Pollut. 140, 492-499.

Dick, J.T.A., Faloon, S.E., Elwood, R.W., 1998. Active brood care in an amphipod: influences of embryonic development, temperature and oxygen. Anim. Behav. $56,663-672$.

Doyotte, A., Cossu, C., Jacquin, M., Babut, M., Vasseur, P., 1997. Antioxidant enzymes, glutathione and lipid peroxidation as relevant biomarkers of experimental or field exposure in the gills and the digestive gland of the freshwater bivalve Unio tumidus. Aquat. Toxicol. 39, 93-110.

Galloway, T.S., 2006. Biomarkers in environmental and human health risk assessment. Mar. Pollut. Bull. 53, 606-613.

Geffard, A., Quéau, H., Dedourge, O., Biagianti-Risboug, S., Geffard, O., 2007. Influence of biotic and abiotic factors on metallothionein level in Gammarus pulex. Comp. Biochem. Physiol. C Toxicol. Pharmacol. 145, 632-640.

Gismondi, E., Cossu-Leguille, C., Beisel, J.N., 2012. Acanthocephalan parasites: help or burden in Gammarid amphipods exposed to cadmium? Ecotoxicology 21, 1188-1193.

Griffith, O.W. 1999. Biologic and pharmacologic regulation of mammalian glutathione synthesis. Free Radical Biol. Med. 27, 922-935.

Hagger, J.A., Jones, M.B., Lowe, D., Leonard, D.P., Owen, R., Galloway, T.S., 2008. Application of biomarkers for improving risk assessments of chemicals under the Water Framework Directive: a case study. Mar. Pollut. Bull. 56, 1111-1118.

Issartel, J., Hervant, F., Voituron, Y., Renault, D., Vernon, P., 2005. Behavioural, ventilatory and respiratory responses of epigean and hypogean crustaceans to different temperatures. Comp. Biochem. Physiol. A Mol. Integr. Physiol. 141, $1-7$.

Jażdżewski, K., 1980. Range extensions of some gammaridean species in european inland waters caused by human activity. Crustaceana 6, 84-107.
Knapen, M.F.C.M., Zusterzeel, P.L.M., Peters, W.H.M., Steegers, E.A.P., 1999. Glutathione and glutathione-related enzymes in reproduction: a review. Eur. J. Obstet. Gynecol. Reprod. Biol. 82, 171-184.

Khan, F.R., Irving, J.R., Bury, N.R., Hogstrand, C., 2011. Differential tolerance of two Gammarus pulex populations transplanted from different metallogenic regions to a polymetal gradient. Aquat. Toxicol. 102, 95-103.

Krog, J., 1954. The influence of seasonal environmental changes upon the metabolism, lethal temperature and rate of heart beat of Gammarus limnaeus (Smith) aken from an Alaskan Lake. Biol. Bull. 107, 397-410.

Kunz, P.Y., Kienle, C., Gerhardt, A., 2010. Gammarus spp. in aquatic ecotoxicology and water quality assessment: toward integrated multilevel tests. Rev. Environ. Contam. Toxicol. 205, 1-76.

Leroy, P., Nicolas, A., Wellmann, M., Michelet, F., Oster, T., Siest, G., 1993. Evaluation of o-phthalaldehyde as bifunctional fluorogenic post-column reagent for glutathione in LC. Chromatographia 36, 130-134.

Meister, A., 1988. Glutathione metabolism and its selective modification. J. Biol Chem. 263, 17205-17208.

Meister, A., Anderson, M.E., 1983. Glutathione. Annu. Rev. Biochem. 52, 711-760.

Parmentier, C., Leroy, P., Wellman, M., Nicolas, A., 1998. Determination of cellular thiols and glutathione-related enzyme activities: versatility of high-performance liquid chromatography-spectrofluorimetric detection. J. Chromatogr. B. 719, 37-46.

Plaistow, S.J., Bollache, L., Cézilly, F., 2003. Energetically costly precopulatory mate guarding in the amphipod Gammarus pulex: causes and consequences. Anim. Behav. 65, 683-691.

Plaistow, S.J., Troussard, J.P., Cézilly, F., 2001. The effect of the acanthocephalan parasite Pomphorhynchus laevis on the lipid and glycogen content of its intermediate host Gammarus pulex. Int. J. Parasitol. 31, 346-351.

Pöckl, M., 1992. Effects of temperature, age and body size on moulting and growth in the freshwater amphipods Gammarus fossarum and G. roeseli. Freshwater Biol. 27, 211-225.

Power, A., Sheehan, D., 1996. Seasonal variation in the antioxidant defense systems of gill and digestive gland of the blue mussel Mytilus edulis. Comp. Biochem. Physiol. C Toxicol. Pharmacol. 114, 99-103.

Regoli, F., Principato, G., 1995. Glutathione, glutathione-dependent and antioxidant enzymes in mussel, Mytilus galloprovincialis, exposed to metals under field and laboratory conditions: implications for the use of biochemical biomarkers. Aquat. Toxicol. 31, 143-164.

Romero-Ruiz, A., Amezcua, O., Rodríguez-Ortega, M.J., Muñoz, J.L., Alhama, J. Rodríguez-Ariza, A., Gómez-Ariza, J.L., López-Barea, J., 2003. Oxidative stress biomarkers in bivalves transplanted to the Guadalquivir estuary after Aznalcóllar spill. Environ. Toxicol. Chem. 22, 92-100.

Rosa, R., Nunes, M.L., 2002. Changes in organ indices and lipid dynamics during the reproductive cycle of Aristeus antennatus, Parapenaeus longirostris, and Nephrops norvegicus (Decapoda) from the portuguese south coast. Crustaceana 75, 1095-1105.

Sies, H., 1986. Biochemistry of oxidative stress. Angew. Chem. Int. Ed. Engl. 25 1058-1071.

Singhal, R., Anderson, M., Meister, A., 1987. Glutathione, a first line of defense against cadmium toxicity. FASEB J. 1, 220-223.

Sornom, P., Felten, V., Médoc, V., Sroda, S., Rousselle, P., Beisel, J.N., 2010. Effect of gender on physiological and behavioural responses of Gammarus roesel (Crustacea Amphipoda) to salinity and temperature. Environ. Pollut. 158 1288-1295.

Sparkes, T.C., Keogh, D.P., Pary, R.A., 1996. Energetic costs of mate guarding behavior in male stream-dwelling isopods. Oecologia 106, 166-171.

Sroda, S., Cossu-Leguille, C., 2011a. Seasonal variability of antioxidant biomarkers and energy reserves in the freshwater gammarid Gammarus roeseli. Chemosphere 83, 538-544.

Sroda, S., Cossu-Leguille, C., 2011b. Effects of sublethal copper exposure on two gammarid species: which is the best competitor? Ecotoxicology 20, 264-273.

Sutcliffe, D.W., 1993. Reproduction in Gammarus (Crustacea, Amphipoda) female strategies. Freshwater Forum 3, 26-64.

Vasseur, P., Leguille, C., 2004. Defense systems of benthic invertebrates in response to environmental stressors. Environ. Toxicol. 19, 433-436.

Verlecar, X., Jena, K., Chainy, G., 2007. Biochemical markers of oxidative stress in Perna viridis exposed to mercury and temperature. Chem. Biol. Interact. 167 219-226.

Verlecar, X. Jena, K. Chainy, G, 2008. Seasonal variation of oxidative biomarkers in gills and digestive gland of green-lipped mussel Perna viridis from Arabian Sea. Estuarine Coastal Shelf Sci. 76, 745-752.

Viarengo, A., Canesi, L., Pertica, M., Livingstone, D.R., 1991. Seasonal variations in the antioxidant defense systems and lipid peroxidation of the digestive gland of mussels. Comp. Biochem. Physiol. C Toxicol. Pharmacol. 100, 187-190.

Wilhelm Filho, D., Tribess, T., Gaspari, C., Claudio, F.D., Torres, M.A., Magalhaes, A.R.M., 2001. Seasonal changes in antioxidant defenses of the digestive gland of the brown mussel (Perna perna). Aquaculture 203, 149-158. 